REGARDS

SUR LIECONOMIE ALLEMANDE

BULLETIN ECONOMIQUE DU CIRAC

\section{Regards sur l'économie allemande}

Bulletin économique du CIRAC

$68 \mid 2004$

Varia

\title{
Droit des sociétés
}

HENS Roland, Vorstandspflichten bei feindlichen Übernahmeangeboten. Eine rechtsvergleichende Untersuchung des US-amerikanischen Rechts, des deutschen Aktienrechts und des WpÜG

\section{(2) OpenEdition}

Édition électronique

URL : http://journals.openedition.org/rea/3638

DOI : 10.4000/rea.3638

ISBN : 978-2-8218-0832-4

ISSN : 1965-0787

\section{Éditeur}

CIRAC

Édition imprimée

Date de publication : 1 octobre 2004

ISSN : 1156-8992

\section{Référence électronique}

"Droit des sociétés », Regards sur l'économie allemande [En ligne], 68 | octobre 2004, mis en ligne le 29 avril 2009, consulté le 22 septembre 2020. URL : http://journals.openedition.org/rea/3638; DOI : https://doi.org/10.4000/rea.3638

Ce document a été généré automatiquement le 22 septembre 2020.

(c) CIRAC 


\section{Droit des sociétés}

HENS Roland, Vorstandspflichten bei feindlichen Übernahmeangeboten. Eine rechtsvergleichende Untersuchung des US-amerikanischen Rechts, des deutschen Aktienrechts und des WpÜG

\section{RÉFÉRENCE}

HENS Roland, Vorstandspflichten bei feindlichen Übernahmeangeboten. Eine rechtsvergleichende Untersuchung des US-amerikanischen Rechts, des deutschen Aktienrechts und des WpÜG, Coll. Schriften zum Wirtschaftsrecht, vol. 170, Duncker \& Humblot, Berlin, 2004, 264 p.

1 Dans quelles conditions le directoire d'une société allemande cotée en bourse a-t-il la possibilité de déjouer une OPA hostile? La réglementation allemande se révèle contradictoire en la matière, et l'auteur de cette thèse de droit comparé plaide pour que le droit allemand des sociétés s'inspire de la législation américaine. (ib) 